\title{
The effects of sacubitril/valsartan and ramipril on the male fertility in hypertensive rats
}

\author{
(1) Duygun Altintas Aykan, ${ }^{1}$ (i) Asli Yaylali, ${ }^{2}$ 을 Nadire Eser, ${ }^{1}$ (i) Muhammed Seyithanoglu, ${ }^{3}$ \\ D Selma Yaman, ${ }^{4}$ (D) Ahmet Cagri Aykan ${ }^{5}$ \\ ${ }^{1}$ Department of Pharmacology, Kahramanmaras Sutcu Imam University Faculty of Medicine, Kahramanmaras, Turkey \\ 2Department of Histology and Embryology, Kahramanmaras Sutcu Imam University Faculty of Medicine, Kahramanmaras, Turkey \\ 3Department of Biochemistry, Kahramanmaras Sutcu Imam University Faculty of Medicine, Kahramanmaras, Turkey \\ ${ }^{4}$ Department of Biophysics, Kahramanmaras Sutcu Imam University Faculty of Medicine, Kahramanmaras, Turkey \\ ${ }^{5}$ Department of Cardiology, Kahramanmaras Sutcu Imam University Faculty of Medicine, Kahramanmaras, Turkey
}

\begin{abstract}
OBJECTIVE: Renin angiotensinogen system (RAS) inhibitors, ramipril and sacubitril/valsartan are frequently used in the treatment of cardiovascular diseases. Although they are known as contraindicated during pregnancy in hypertensive women, there is not any outcome of their safety in male fertility after exposure to ramipril or sacubitril/valsartan. In this study, we aimed to evaluate the effects of ramipril and sacubitril/valsartan to highlight their safety in the male fertility in normotensive and hypertensive rats.
\end{abstract}

METHODS: Adult male normotensive and dexamethasone-induced hypertensive rats were treated with sacubitril/valsartan, ramipril and saline for 18 days. Arterial blood pressures were verified using carotid artery cannulation. Male fertility parameters, including the testis weights, histopathologic scoring of the testis, sperm count, sperm motility, morphology, and serum testosterone levels, were analyzed in treated and nontreated normotensive/hypertensive rats.

RESULTS: Sacubitril/valsartan or ramipril treatments did not reveal a significant difference in sperm production, testicular morphology, and radioimmunoassay of serum testosterone levels compared to the control group. However, sperm motility was significantly reduced in rats under RAS inhibition.

CONCLUSION: This finding was likely mediated by the identification of Ang receptors in the tails of rat sperm given that Ang receptors may play a role in the modulation of sperm motility. Identification of RAS-related proteins involved in sperm motility may help to explain their roles in motility. Our data provide general safety evidence for the male fertilization ability after paternal sacubitril/valsartan and ramipril exposure.

Keywords: Paternal exposure; ramipril; sacubitril-valsartan; spermatozoa.

Cite this article as: Altintas Aykan D, Yaylali A, Eser N, Seyithanoglu M, Yaman S, Aykan AC. The effects of sacubitril/valsartan and ramipril on the male fertility in hypertensive rats. North Clin Istanb 2020;7(5):425-432.

$\mathrm{P}$ aternal drug exposure is defined as the agents that a male partner has been exposed to [1]. The physiological or environmental factors that induce and maintain sperm production and motility generally remain unclear, although several agents have been reported to be involved.
In recent years, studies have been conducted on the physiological and pathophysiological relationship of the human reproductive system and renin angiotensinogen system (RAS) $[2,3]$. The presence of RAS components in the reproductive system, especially in oocytes, granu-

Received: September 01, 2019 Accepted: May 29, 2020 Online: August 05, 2020

Correspondence: Duygun ALTINTAS AYKAN, MD. Kahramanmaras Sutcu Imam Universitesi Tip Fakultesi, Farmakoloji Anabilim Dali, Kahramanmaras, Turkey.

Tel: +90 5074276659 e-mail: altintasduygun_dr@yahoo.com

(c) Copyright 2020 by Istanbul Provincial Directorate of Health - Available online at www.northclinist.com 
lar cells, sperm cells and Leydig cells have been described previously [4]. In addition, RAS pathways have been reported to play a role in reproductive functions. Angiotensin-converting enzyme 1 (ACE1), a key enzyme in RAS, converts angiotensin I (Ang I) to angiotensin II (Ang II) and has been involved in female reproductive physiology through Ang II type 1 receptor (AT1R) and Ang II type 2 receptor (AT2R). In contrast, the functions of Ang II in male reproductive events were reported to be stimulated by the Ang II type 1 receptor (AT1R) [5].

Sacubitril/valsartan, a combined form of 'neprilysin inhibitor' and 'angiotensin receptor blocker (ARB)', is used in the management of cardiovascular diseases. Sacubitril, a neprilysin inhibitor, inhibits degradation of the endogenous natriuretic peptides, thus enhancing their beneficial cardiovascular effects. Valsartan, an ARB, displaces Ang II from AT1R and antagonizes AT1-induced vasoconstriction. Although many studies have extensively examined the potentially toxic effects of drugs in female reproduction, the experience of fertility after paternal drug exposure is limited. It is reported that the women of reproductive age should avoid this combination since $\mathrm{ARB}$ s have been associated with fetal renal dysfunction and oligohydramnios [6].

Ramipril, an ACE inhibitor, similarly, is not recommended for the treatment of uncomplicated hypertension in pregnancy and is reported as contraindicated by several guidelines in the treatment of hypertension and chronic heart failure during pregnancy. Animal studies were conducted on the female species, but male exposure to the RAS inhibitors has not been investigated $[6,7]$.

In general, there are very few human data related to the paternal exposure to the medications regarding their potential toxic effects on male fertility or reproductivity. This uncertainty increases the anxiety both in the families and the physician who received the drug to the father, although it is generally thought that the maternal drug exposure is more important for the off-spring [8]. In this study, we aimed to evaluate the paternal exposure to RAS-related drugs, sacubitril/valsartan and ramipril, to highlight their effects in male fertility, and compare the fertility parameters of normotensive and hypertensive male rats after drug exposure.

\section{MATERIALS AND METHODS}

\section{Animals}

In this experimental animal study, a total number of thirty-six adult male Wistar-Albino rats (body weight of
$200-300 \mathrm{~g}$ ) were housed and maintained at $22^{\circ} \mathrm{C}, 60 \pm 5 \%$ humidity and a $12: 12 \mathrm{~h}$ light/dark cycle with free access to food and water. The procedures used and the care of animals was approved by the Institutional Animal Care and Use Committee (Approval No. 2018/01/06, Approval date: 13.02.2018). All experiments were conducted in strict accordance with the National Institute of Health Guidelines for the Care and Use of Laboratory Animals.

\section{Drugs and Chemicals}

Dexamethasone was purchased from Deva (Istanbul, Turkey), ramipril was purchased from Sanofi (Istanbul, Turkey), and sacubitril/valsartan was supplied from Novartis Farma S.p.A (Torre Annunziata, Italy). Ramipril and sacubitril/valsartan were freshly prepared at doses of $10 \mathrm{mg} / \mathrm{kg} / \mathrm{d}$ per day and $80 \mathrm{mg} / \mathrm{kg} / \mathrm{d}$ per day, respectively, homogeneously dissolved in water and administered to rats with orogastric gavage. Dexamethasone $(30 \mu \mathrm{g} /$ $\mathrm{kg}$ per day) and sterile saline (sodium chloride) were administered subcutaneously at a volume of $1 \mathrm{ml} / \mathrm{kg}$.

\section{Experimental Design and Hypertensive Rat Model}

A total number of thirty-six male Wistar-Albino rats were randomly divided into six groups $(n=6)$. Dexamethasone $(30 \mu \mathrm{g} / \mathrm{kg})$ was applied subcutaneously (s.c.) between $4-18^{\text {th }}$ days of the experiment to form the hypertensive rat model. Blood pressures were verified with mean arterial blood pressure (MABP) measurements using carotid artery cannulation according to the method of Bilanda et al. [9]. Treatment groups were as follows:

Group 1: normotensive control (untreated rats with normal blood pressure),

Group 2: normotensive ramipril (rats with normal blood pressure received ramipril $10 \mathrm{mg} / \mathrm{kg}$ ),

Group 3: normotensive sacubitril/valsartan (rats with normal blood pressure received sacubitril/valsartan $80 \mathrm{mg} / \mathrm{kg}$ ),

Group 4: hypertensive control (untreated rats with high blood pressure),

Group 5: hypertensive ramipril (rats with high blood pressure received ramipril $10 \mathrm{mg} / \mathrm{kg}$ ),

Group 6: hypertensive sacubitril/valsartan (rats with high blood pressure received sacubitril/valsartan 80 $\mathrm{mg} / \mathrm{kg}$ ).

This model of hypertension is usually attributed to the activation of the steroid-induced mineralocorticoid receptor, but studies have shown that glucocorticoids 
may also increase blood pressure independently of this receptor. In addition, one of the underlying mechanisms of steroid-induced hypertension is the increase of endogenous vasoconstrictive agents such as norepinephrine and angiotensin II [10]. Thus, in our protocols, antihypertensive medications were administered between $0-18^{\text {th }}$ days of the experiment for already blocking the receptors that are responsible for dexamethasone-induced hypertension. The doses in this study were calculated on the basis of doses that have been shown to have antihypertensive effects in the rat model of hypertension in our previous studies [11].

Mean arterial blood pressure of hypertensive groups (Group 4, 5, 6) was verified before the assessment of fertility parameters. The mean arterial blood pressures were as follows: Group 4 (untreated rats with high blood pressure): $132 \pm 7 \mathrm{mmHg}$, Group 5 (rats with high blood pressure received ramipril $10 \mathrm{mg} / \mathrm{kg}$ ): $114 \pm 8 \mathrm{mmHg}$, Group 6 (rats with high blood pressure received sacubitril/valsartan $80 \mathrm{mg} / \mathrm{kg}$ ): 109 $\pm 11 \mathrm{mmHg}$.

At the end of the experiment, testis weights, histopathologic scoring of testis according to the modified Johnsen scoring [12], sperm count, sperm motility, morphologic evaluations due to head and tail anomalies [13], and serum testosterone levels of rats were analyzed.

\section{Assessment of Mean Arterial Blood Pressure (MABP) using Carotid Artery Cannulation}

Arterial blood pressure of all rats was measured as previously described. [5] Briefly, the rat was anesthetized using an intraperitoneal injection of ketamine $(80 \mathrm{mg} / \mathrm{kg})$ and xylazine $(10 \mathrm{mg} / \mathrm{kg})$. The trachea was exposed and cannulated to facilitate spontaneous breathing. The arterial blood pressure was measured from the carotid artery using an arterial cannula connected to a pressure transducer coupled with a hemodynamic recorder (BIOPAC MP35 System Inc., Santa Barbara, CA, USA).

\section{Histopathological Assay}

At the end of drug treatments, testis, epididymis and seminal vesicles were isolated from the rats and cleaned from peripheral connective tissue. The weights of testis were measured with the Mettler Toledo precision weighing device. The right testis was taken immediately and fixed in Bouin's solution for $24 \mathrm{hr}$. After 24 hours of fixation, the testis tissues were embedded in paraffin. The $5-\mu \mathrm{m}$ thick sections were obtained and stained with hematoxylin and eosin. The groups were evaluated using an Olympus BX43 (To- kyo, Japan) microscope, according to the modified Johnsen scoring system, as briefly described [12]. Testicular biopsy score of Johnsen count is a method for registration of spermatogenesis in testes. Each tubular section was given a score from 10 to 1 according to the presence or absence of the main cell types arranged in the order of maturity. Presence of spermatozoa scores 10, 9 or 8; spermatids (and no further) 7 or 6 ; spermatocytes (and no further) 5 or 4 ; only spermatogonia 3, only Sertoli cells 2 and no cells 1 .

\section{Analysis of Sperm Motility, Count and Morphology}

Epididymal sperm analysis, including motility, count and abnormal morphology rates, was carried out as described previously [13]. The left epididymis of each rat was removed. Epididymal plasma was obtained by cutting the caudal part of the left epididymis in a petri dish. The seminal plasma was kept for two minutes at room temperature to be liquefied. Semen sample was taken into GMOPS plus (Vitrolife, USA) solution. After centrifugation using the routine gradient method, the pellet was centrifuged again by dilution with the sperm washing medium (Vitrolife, USA). The sperm count and motility in the Makler chamber (Sefi Medical Instruments, Haifa, Israel) were evaluated using the Olympus BX43 microscope (Tokyo, Japan). The semen fluid was spread on the lam and left to dry. It was subsequently dyed by Diff Quick (NBT Lab) staining method for morphological evaluation. Under x100 magnification using the immersion oil, the total area of 100 spermatozoa was counted and percentage values regarding the disorders in the morphology and structure of head or tail were given.

\section{Enzyme-Linked Immunosorbent Assay (ELISA)}

After drug treatments with sacubitril/valsartan and ramipril, blood sampling was collected by cardiac puncture under anesthetic conditions. Concentrations of testosterone in the plasma were measured by ELISA according to the manufacturer's instructions. The kit by which testosterone analyzed was 201-11-5126; from SunRed Biological Technology, Shanghai, China. In ELISA for testosterone, the sensitivity of the assay was $8.775 \mathrm{pg} /$ $\mathrm{ml}$; assay range was $10 \mathrm{pg} / \mathrm{ml}-3000 \mathrm{pg} / \mathrm{ml}$ with an intra-assay coefficient of variations $<10 \%$, inter-assay coefficient of variations $<11 \%$.

\section{Data Analysis}

The data were defined as the arithmetic average and standard deviation. To apply parametric tests, the 
TABLE 1. Male fertility values in normotensive and hypertensive rats; before (control) and after drug treatments (ramipril, sacubitril/valsartan)

\begin{tabular}{lccccc} 
Variable & $\begin{array}{c}\text { Serum testosterone } \\
(\mathrm{pg} / \mathrm{ml})\end{array}$ & $\begin{array}{c}\text { Testicular biopsy } \\
\text { score }\end{array}$ & $\begin{array}{c}\text { Sperm count } \\
\left(\mathrm{nx} 10^{4}\right)\end{array}$ & $\begin{array}{c}\text { Sperm motility } \\
(\%)\end{array}$ & $\begin{array}{c}\text { Testis weight } \\
(\text { grams })\end{array}$ \\
\hline Normotensive-control & $76.92 \pm 41.19$ & $9.83 \pm 0.41$ & $75.50 \pm 13.63$ & $43.50 \pm 10.69$ & $1.65 \pm 0.28$ \\
Normotensive-rami & $85.06 \pm 26.83$ & $9.67 \pm 0.52$ & $67.83 \pm 16.82$ & $31.67 \pm 9.75^{*}$ & $1.83 \pm 0.51$ \\
Normotensive-sacu/val & $70.70 \pm 23.36$ & $9.17 \pm 0.75$ & $60.83 \pm 14.86$ & $33.67 \pm 7.76^{* *}$ & $1.80 \pm 0.20$ \\
HT-control & $51.11 \pm 18.16$ & $9.33 \pm 0.82$ & $70.00 \pm 13.36$ & $25.83 \pm 5.91^{\text {a }}$ & $1.82 \pm 0.75$ \\
HT-rami & $103.19 \pm 88.37$ & $9.67 \pm 0.52$ & $63.33 \pm 14.99$ & $28.17 \pm 6.15^{\mathrm{b}}$ & $1.83 \pm 0.18$ \\
HT-sacu/val & $68.32 \pm 61.73$ & $9.33 \pm 0.82$ & $65.83 \pm 12.84$ & $30.33 \pm 7.79^{\mathrm{c}}$ & $1.73 \pm 0.12$ \\
\hline
\end{tabular}

Rami: Ramipril; Sacu/val: Sacubitril/ valsartan. The p-values for the sperm motility comparing normotensive control group versus normotensive ramipril, normotensive sacu/val, HT control, HT ramipril, HT sacu/val groups respectively; *: p=0.018; **: p=0.046; a: $p<0.001 ; b: p=0.003 ; c: p=0.009$.
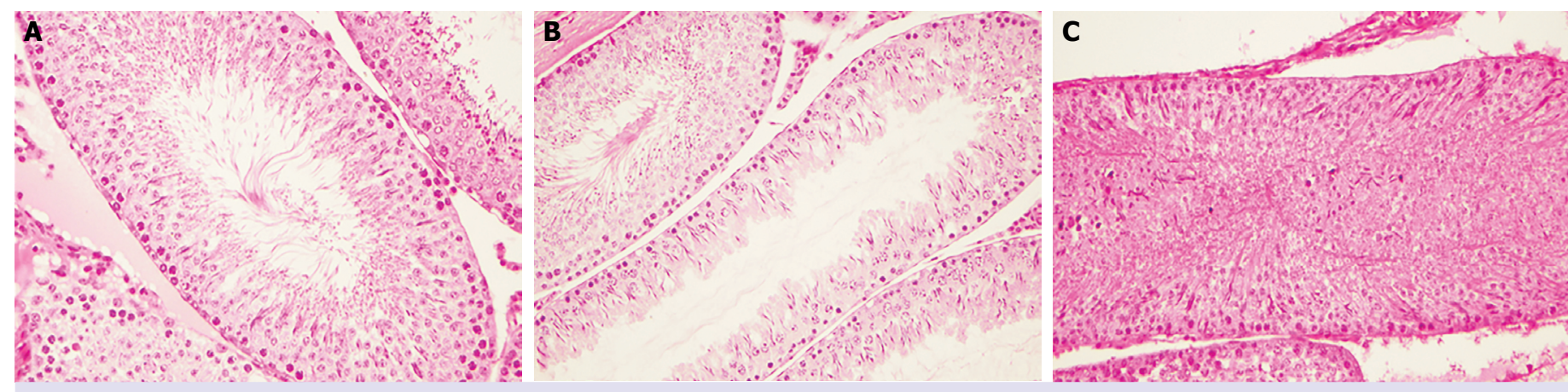

FIGURE 1. (A) Normal morphology of the germinal epithelium, spermatogenetic series cells, sertoli and leydig cells in normotensive control rats (x200). (B) Normotensive treatment groups with normal testicular architecture and morphology (x200). (C) Hypertension affected seminiferous tubule appearance (x200).

Kolmogorov Smirnov test was used to determine whether the samples have a normal distribution and whether the variances are homogeneous. For multiple groups, analysis of variance test with post-hoc Tukey's test for significant difference was used for normally distributed data. Kruskal Wallis test with Mann-Whitney $U$ test under Bonferroni correction was used for the analysis of none normally distributed data. The p-values less than 0.05 were considered significant. The data were evaluated at a $95 \%$ confidence interval. The data were analyzed in SPSS 17.0 programme (IBM, IL, U.S.A.).

\section{RESULTS}

Effects of Mean Arterial Blood Pressure on Male Fertility

In the hypertensive control rats, mean testosterone level was $51.11 \pm 18.16 \mathrm{pg} / \mathrm{ml}$, mean testicular biopsy score was $9.33 \pm 0.82$, mean sperm count was $70.00 \pm 13.36$ (x104), mean sperm motility was $25.83 \pm 5.91$ (\%), and mean testis weight was $1.82 \pm 0.75 \mathrm{~g}$ (Table 1). Among these parameters, we found that sperm motility significantly reduced in all groups compared to the normotensive control rats $(43.50 \pm 10.69 \%)$.

\section{Effects of Treatments on Histopathological Scoring}

We found that rats treated with ramipril or sacubitril/ valsartan did not cause a significant change in the histopathological scoring parameters in comparison to the control group. Upon microscopic examination, animals in the control and treatment groups revealed a normal testicular architecture and morphology with spermatogenic cells at different stages of development (Fig. 1A, B). Hypertension revealed an insignificant reduction in spermatogenesis compared to that of control by affecting the seminiferous tubule appearance $(9.33 \pm 0.82$ versus

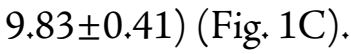


TABLE 2. Morphologic evaluation of sperms in normotensive and hypertensive rats before (control) and after drug treatments (ramipril, sacubitril/valsartan)

\begin{tabular}{lcccccc} 
Morphological assessment & $\begin{array}{c}\text { Normotensive- } \\
\text { control (\%) }\end{array}$ & $\begin{array}{c}\text { Normotensive- } \\
\text { rami (\%) }\end{array}$ & $\begin{array}{c}\text { Normotensive- } \\
\text { sacu/val (\%) }\end{array}$ & $\begin{array}{c}\text { HT-control } \\
(\%)\end{array}$ & $\begin{array}{c}\text { HT-rami } \\
(\%)\end{array}$ & $\begin{array}{c}\text { HT-sacu/val } \\
(\%)\end{array}$ \\
\hline Normal morphology & 96 & 94 & 93 & 95 & 93 & 94 \\
Head anomaly & 2 & 4 & 3 & 3 & 4 & 3 \\
Tail anomaly & 2 & 2 & 4 & 2 & 3 & 3 \\
\hline
\end{tabular}

HT: Hypertensive; Rami: Ramipril; Sacu/val: Sacubitril/ valsartan.
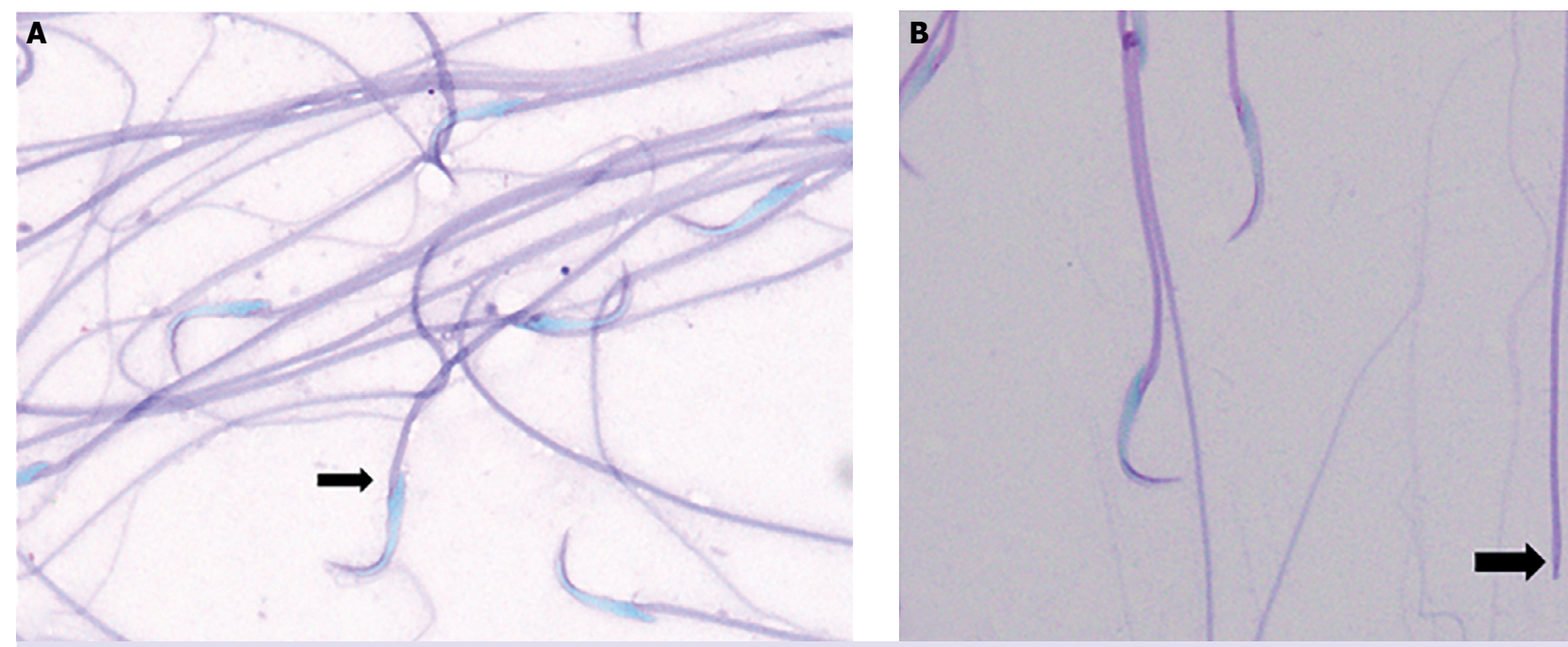

FIGURE 2. (A) Arrow shows a head anomaly in hypertensive rats (x1000). (B) Arrow shows a tail anomaly in hypertensive rats (x1000).

Effects of Treatments on Sperm Motility, Count and Morphology

The results of the sperm motility, count and morphology were presented in Table 1 and Table 2. Table 1 presented that the treatment of normotensive rats with ramipril and sacubitril/valsartan decreased the sperm count compared to the normotensive control rats $(67.83 \pm 16.82$, $60.83 \pm 14.86$ versus $75.50 \pm 13.63 \times 104)$. In addition, the treatment of hypertensive rats with ramipril and sacubitril/valsartan decreased the sperm count compared to the hypertensive control rats $(63.33 \pm 14.99$, $65.83 \pm 12.84$ versus $70.00 \pm 13.36 \times 104)$. However, these reductions were found insignificant.

Ramipril, sacubitril/valsartan, and high blood pressure significantly decreased the sperm motility compared to the normotensive control rats, as shown in Table $1(31.67 \pm 9.75 \%, 33.67 \pm 7.76 \%$, $25.83 \pm 5.91 \%, 28.17 \pm 6.15 \%$ versus $43.50 \pm 10.69 \%)$.
Figure 2 showed head and tail anomaly in hypertensive rats $(\mathrm{x} 1000)$.

\section{Effects of Treatments on Serum Testosterone Levels}

As shown in Table 1, the exposure to ramipril or sacubitril/valsartan did not significantly affect the testosterone level of serum compared to the control group. We found that testosterone levels of hypertensive rats were insignificantly reduced in comparison with a normotensive group $(51.11 \pm 18.16 \mathrm{pg} / \mathrm{ml}$ versus $76.92 \pm 41.19$ $\mathrm{pg} / \mathrm{ml}$ ) (Table 1).

\section{Effects of Treatments on Testis Weights}

The exposure to ramipril or sacubitril/valsartan did not result in any significant changes in the weights of the testis compared to the control group $(1.83 \pm 0.51 \mathrm{~g}$ and $1.80 \pm 0.20$ g versus $1.65 \pm 0.28 \mathrm{~g}$ ). Furthermore, we found no significant difference in the weights of hyper- 
tensive rats' testis in comparison with a normotensive group $(1.82 \pm 0.75 \mathrm{~g}$ versus $1.65 \pm 0.28 \mathrm{~g})$ (Table 1$)$.

\section{DISCUSSION}

It was well established that the drugs acting directly on the RAS may cause injury and death to the developing fetus if used by pregnant women during the first trimester [14]; however, this finding may also be confounded by maternal hypertensive disease, as chronic maternal hypertension is associated with adverse events in the fetus [6]. It is also necessary to pay attention to the drugs that the father inadvertently uses, which may exert toxic reactions on the male fertility parameters. Likewise, the male reproductive system and male genitourinary pathways have several local RAS activities. The roles of the RAS in local processes at these sites are still uncertain, although there is evidence for involvement in tubular contractility, spermatogenesis, sperm maturation, capacitation, acrosomal exocytosis and fertilization [15].

Three main mechanisms of male reproductive toxicity have been proposed in previous studies: nongenetic toxicity due to the presence of a chemical compound or drug in semen, genetic toxicity involving gene mutation and/or chromosomal abnormality, and epigenetic toxicity which affects gene expression, genomic imprinting or DNA methylation [16]. Paternal chronic exposure to 5-azacytidine, cyclophosphamide and tamoxifen has revealed a decrease in genomic methylation of epididymal sperm in previous studies [17-19]. Furthermore, many drugs have been reported to lead to the temporary or persistent infertility by impairing semen parameters [1]. Paternal radiotherapy and some antineoplastic agents may cause male germ cell loss due to the doses of the exposed agent and duration of treatment $[20,21]$. In the current study, we analyzed the RAS inhibitors on the male fertility in hypertensive and normotensive rats and found that the sperm motility significantly reduced in hypertensive rats after treatments with RAS inhibitors, although there were no significant changes in the sperm production or morphology.

Male fertility is particularly impaired by the reduction in sperm count, delay in sexual maturation, decrease in serum testosterone levels, apoptosis of germ cell, and testicular inflammation [22]. Many drugs may cause decreases in sperm count, but these adverse effects are manifested in different time periods. Due to the toxicity of late-stage germ cells, a $10-100$ fold reduction in sperm count may occur in one to two months. However, azoospermia usually does not occur until two months when the sperm would be derived from differentiating spermatogonia [23]. The process of spermatogenesis normally takes about 52-53 days in rats; however, the development of the seminiferous epithelium cycle or the spermatogenetic cycle is segmental in rats, has fourteen stages and takes place in 287.7 hours (twelve days), while in human it is helical, has six stages and occurs in 384.6 hours (sixteen days) [24]. Thus, in our study, we evaluated the sperm count in rats at the end of the drug treatments on the 18.day since one or more stages of this spermatogenic process can be altered by the medications administered during a period of 18-days. We found that ramipril and sacubitril/valsartan revealed an insignificant decrease in the sperm count compared to the normotensive control rats.

The male reproductive organ weights are used as valuable markers for reproductive risk assessment. The reduction in the testicular weights could be due to the germinal cell loss [25]. Exposure to ramipril, sacubitril/ valsartan or high blood pressure resulted in no significant change in the weights of the testis compared to the control group. Sertoli cells form tight junctions that are the parts of the blood-testis barrier to protect spermatogenesis, provide nutrients and immunosuppressive factors for the germ cells [22]. Disruption of the Sertoli cell-germ cell association by cytotoxic agents, diseases, oxidative stress, or inflammation impairs spermatogenesis [26]. In our study, we found that animals in the control and treatment groups revealed a normal testicular architecture and morphology with spermatogenic cells at different stages of development. However, hypertension affected the seminiferous tubule appearance and revealed an insignificant reduction in spermatogenesis, compared to that of control. These findings were in accordance with previous reports that high blood pressure induced testicular morphological alterations in seminiferous tubules and intratesticular vessels, associated with lower spermatozoid concentration [27].

Changes in sperm quality and/or motility may be associated with impaired testosterone production and expression in the steroidogenesis after drug use [28]. To clarify this hypothesis, we evaluated the levels of serum testosterone levels using ELISA assay in normotensive and hypertensive male rats under treatment with RAS inhibitors. We found that testosterone levels of hypertensive rats were insignificantly reduced compared to the normotensive group, and ramipril or sacubitril/valsartan did not significantly affect the serum testosterone levels. 
The RAS was reported to be related to androgen synthesis. Activation of AT1R increases luteinizing hormone and corticotrophin-releasing hormone, which stimulates adrenal glands to secrete androgen precursors and testis for androgen production [29]. The effects of AngII infusion and ACE inhibition on the RAS activity have also been examined in the testes. In previous studies, the infusion of AngII decreased the local synthesis of testicular ACE mRNA, indicating that a local RAS activity is responsive to RAS inhibition [30]. In human studies, there have been limited studies on the effects of ACE inhibitors on androgen metabolism in men. Lisinopril in hypertensive men showed a significant decrease in free testosterone [31], but no significant changes in serum testosterone level were observed in another study with ramipril [32].

Sperm motility is a key parameter for fertilization. Motility and sperm flagellum are required for sperm to cross the protective layers around the oocyte and to deliver its DNA content into the oocyte [33]. As a result, any deterioration in sperm motility has a strong inhibitory effect on the fertilization and adversely affects fertility [34]. Ang II plays a role in maintaining sperm function and fertility. Exposure of sperm to Ang II increases the percentage of motile spermatozoa. In addition, this peptide has been associated with capacitation and acrosome reaction $[2,35]$. Local tissue RAS is found in both male and female genital tracts, including angiotensinogen mRNA and renin in rat testes. Previous studies have identified AT1R and AT2R in the tail of the rat and human sperm $[36,37]$. Accordingly, we found that the sperm motility significantly reduced in hypertensive rats after treatments with RAS inhibitors.

It was reported that Ang II increased the percentage of motile sperm and that AT1R antagonists inhibited the effects of Ang II on the percentage of motile sperm. Human seminal fluid contains prorenin, and the development of sperm requires $\mathrm{ACE}$ isozyme involved in sperm capacitation [36]. Male mice with ACE deficiency subsequent a mutation formation that was designed to inactivate both testis and non-testis forms of ACE have been identified as infertile, although sperm production and mating behavior appear to be normal [38]. These data show that RAS plays a significant role in the regulation of sperm motility function. In addition, since this effect was eliminated in the presence of ACE inhibitor ramipril, it is clear that Ang I, as well as Ang II, was found to increase the percentage of motile sperm. In another study, male mice that were homozygous in the lacking an angiotensinogen gene were found fertile, though this condition was usually fatal [39].
Our experimental study has some limitations. RAS inhibition or deficiency alone may not be sufficient to correlate with changes in sperm motility, and it is important to consider the other measurements of sperm function to elucidate the role of Ang II. In fact, instead of the decrease in sperm motility with RAS inhibition, the lack of a clear dose-response relationship suggests that Ang stimulation may not play a primary role in this event. Secondly, we could not determine whether paternal sacubitril/valsartan and ramipril exposure could cause gene mutation, chromosomal abnormality on gene expression, genomic imprinting or DNA methylation in male sperm and whether these changes could pass to the offspring.

In conclusion, the importance of RAS in male fertility was demonstrated by significantly reduced sperm motility under RAS inhibition in male rats, although sperm production and morphology appear normal. This finding was likely to be mediated by the identification of Ang receptors in the tails of rat sperm, the presence of local tissue RAS, renin and angiotensinogen mRNA in male tracts. Ang receptors may play a role in the modulation of sperm motility due to its presence in the human semen. Identification of RAS-related proteins involved in sperm motility may help to explain their roles in motility. This experimental study has limited power; however, our data provide general safety evidence for the male fertilization ability after paternal sacubitril/valsartan and ramipril exposure.

Ethics Committee Approval: The procedures used and the care of animals were approved by the Instutional Animal Care and Use Committee in Kahramanmaras Sutcu Imam University (Approval No. 2018/01/06, Approval date: 13.02.2018).

Conflict of Interest: No conflict of interest was declared by the authors.

Financial Disclosure: The authors declared that this study has received no financial support.

Authorship Contributions: Concept - DAA; Design - DAA, ACA; Supervision - ACA; Fundings - DAA, AY, MS; Materials - DAA, AY, $\mathrm{NE}, \mathrm{MS}$, SY; Data collection and/or processing - DAA, AY, NE, MS, SY; Analysis and/or interpretation - DAA, ACA, NE; Literature review - DAA, SY; Writing - DAA; Critical review - ACA.

\section{REFERENCES}

1. De Santis M, Cesari E, Cavaliere A, Ligato MS, Nobili E, Visconti D, et al. Paternal exposure and counselling: experience of a Teratology Information Service. Reprod Toxicol 2008;26:42-6. [CrossRef]

2. Gianzo M, Muñoa-Hoyos I, Urizar-Arenaza I, Larreategui Z, Quintana F, Garrido N, Subirán N, et al. Angiotensin II type 2 receptor is expressed in human sperm cells and is involved in sperm motility. Fertil Steril 2016;105:608-16. [CrossRef] 
3. Reis AB, Araújo FC, Pereira VM, Dos Reis AM, Santos RA, Reis FM. Angiotensin (1-7) and its receptor Mas are expressed in the human testis: implications for male infertility. J Mol Histol 2010;41:75-80.

4. Leal MC, Pinheiro SV, Ferreira AJ, Santos RA, Bordoni LS, Alenina N, et al. The role of angiotensin-(1-7) receptor Mas in spermatogenesis in mice and rats. J Anat 2009;214:736-43. [CrossRef]

5. Pan PP, Zhan QT, Le F, Zheng YM, Jin F. Angiotensin-converting enzymes play a dominant role in fertility. Int J Mol Sci 2013;14:2107186. [CrossRef]

6. American College of Obstetricians and Gynecologists; Task Force on Hypertension in Pregnancy. Hypertension in pregnancy. Report of the American College of Obstetricians and Gynecologists' Task Force on Hypertension in Pregnancy. Obstet Gynecol 2013;122:1122-31.

7. European Society of Gynecology (ESG); Association for European Paediatric Cardiology (AEPC); German Society for Gender Medicine (DGesGM), Regitz-Zagrosek V, Blomstrom Lundqvist C, Borghi C, Cifkova R, Ferreira R, Foidart JM, et al; ESC Committee for Practice Guidelines. ESC Guidelines on the management of cardiovascular diseases during pregnancy: the Task Force on the Management of Cardiovascular Diseases during Pregnancy of the European Society of Cardiology (ESC). Eur Heart J 2011;32:3147-97. [CrossRef]

8. Kruger TF, DuToit TC, Franken DR, Acosta AA, Oehninger SC, Menkveld R, et al. A new computerized method of reading sperm morphology (strict criteria) is as efficient as technician reading. Fertil Steril 1993;59:202-9. [CrossRef]

9. Bilanda DC, Dimo T, Dzeufiet Djomeni PD, Bella NM, Aboubakar OB, Nguelefack TB, et al. Antihypertensive and antioxidant effects of Allanblackia floribunda Oliv. (Clusiaceae) aqueous extract in alcohol- and sucrose-induced hypertensive rats. J Ethnopharmacol 2010;128:634-40. [CrossRef]

10. d'Emmanuele di Villa Bianca R, Mitidieri E, Donnarumma E, Tramontano T, Brancaleone V, Cirino G, et al. Hydrogen sulfide is involved in dexamethasone-induced hypertension in rat. Nitric Oxide 2015;46:80-6. [CrossRef]

11. Aykan DA, Koca TT, Yaman S, Eser N. Angiotensin converting enzyme and neprilysin inhibition alter pain response in dexhamethasoneinduced hypertensive rats. Pharmacol Rep 2019;71:306-10. [CrossRef]

12. Johnsen SG. Testicular biopsy score count--a method for registration of spermatogenesis in human testes: normal values and results in 335 hypogonadal males. Hormones 1970;1:2-25. [CrossRef]

13. Yokoi K, Uthus EO, Nielsen FH. Nickel deficiency diminishes sperm quantity and movement in rats. Biol Trace Elem Res 2003;93:141-54.

14. Seely EW, Ecker J. Chronic hypertension in pregnancy. Circulation 2014;129:1254-61. [CrossRef]

15. Leung PS, Sernia C. The renin-angiotensin system and male reproduction: new functions for old hormones. J Mol Endocrinol 2003;30:26370. [CrossRef]

16. Trasler JM, Doerksen T. Teratogen update: paternal exposures-reproductive risks. Teratology 1999;60:161-72. [CrossRef]

17. Doerksen T, Trasler JM. Developmental exposure of male germ cells to 5 -azacytidine results in abnormal preimplantation development in rats. Biol Reprod 1996;55:1155-62. [CrossRef]

18. Barton TS, Robaire B, Hales BF. Epigenetic programming in the preimplantation rat embryo is disrupted by chronic paternal cyclophosphamide exposure. Proc Natl Acad Sci U S A 2005;102:7865-70.

19. Kedia-Mokashi NA, Kadam L, Ankolkar M, Dumasia K, Balasinor NH. Aberrant methylation of multiple imprinted genes in embryos of tamoxifen-treated male rats. Reproduction 2013;146:155-68. [CrossRef]

20. Sabanegh ES Jr, Ragheb AM. Male fertility after cancer. Urology 2009;73:225-31. [CrossRef]
21. Howell S, Shalet S. Gonadal damage from chemotherapy and radiotherapy. Endocrinol Metab Clin North Am 1998;27:927-43. [CrossRef]

22. Jin M, Lou J, Yu H, Miao M, Wang G, Ai H, et al. Exposure to 2,3,7,8-tetrachlorodibenzo-p-dioxin promotes inflammation in mouse testes: The critical role of Klotho in Sertoli cells. Toxicol Lett 2018;295:134-43. [CrossRef]

23. Meistrich ML. Effects of chemotherapy and radiotherapy on spermatogenesis in humans. Fertil Steril 2013;100:1180-6. [CrossRef]

24. Wankeu-Nya M, Florea A, Bâlici S, Watcho P, Matei H, Kamanyi A. Dracaena arborea alleviates ultra-structural spermatogenic alterations in streptozotocin-induced diabetic rats. BMC Complement Altern Med 2013;13:71. [CrossRef]

25. Supriya Ch, Reddy PS. Prenatal exposure to aflatoxin B1: developmental, behavioral, and reproductive alterations in male rats. Naturwissenschaften 2015;102:26. [CrossRef]

26. Ma Y, Yang HZ, Xu LM, Huang YR, Dai HL, Kang XN. Testosterone regulates the autophagic clearance of androgen binding protein in rat Sertoli cells. Sci Rep 2015;5:8894. [CrossRef]

27. Bechara GR, de Souza DB, Simoes M, Felix-Patrício B, Medeiros JL $\mathrm{Jr}$, Costa WS, et al. Testicular Morphology and Spermatozoid Parameters in Spontaneously Hypertensive Rats Treated with Enalapril. J Urol 2015;194:1498-503. [CrossRef]

28. Bielas W, Niżański W, Nicpoń J, Nicpoń JE, Partyka A, Mordak R, et al. Effect of zearalenone on circulating testosterone concentration, testicular and epididymal morphology and epididymal sperm characteristics in wild boars. Theriogenology 2017;102:59-66. [CrossRef]

29. Kwok T, Ohlsson C, Vandenput L, Tang N, Zhang YF, Tomlinson B, et al. ACE inhibitor use was associated with lower serum dehydroepiandrosterone concentrations in older men. Clin Chim Acta 2010;411:1122-5. [CrossRef]

30. Schunkert H, Ingelfinger JR, Hirsch AT, Pinto Y, Remme WJ, Jacob H, et al. Feedback regulation of angiotensin converting enzyme activity and mRNA levels by angiotensin II. Circ Res 1993;72:312-8. [CrossRef]

31. Koshida H, Takeda R, Miyamori I. Lisinopril decreases plasma free testosterone in male hypertensive patients and increases sex hormone binding globulin in female hypertensive patients. Hypertens Res 1998;21:279-82. [CrossRef]

32. Grönroos PE, Irjala KM, Vesalainen RK, Kantola IM, Leinonen VM, Helenius TI, et al. Effects of ramipril on the hormone concentrations in serum of hypertensive patients. Eur J Clin Chem Clin Biochem 1997;35:411-4. [CrossRef]

33. Ravaux B, Garroum N, Perez E, Willaime H, Gourier C. A specific flagellum beating mode for inducing fusion in mammalian fertilization and kinetics of sperm internalization. Sci Rep 2016;6:31886. [CrossRef]

34. Publicover SJ, Barratt CL. Sperm motility: things are moving in the lab!. Mol Hum Reprod 2011;17:453-6. [CrossRef]

35. Sabeur K, Vo AT, Ball BA. Effects of angiotensin II on the acrosome reaction in equine spermatozoa. J Reprod Fertil 2000;120:135-42.

36. Vinson GP, Mehta J, Evans S, Matthews S, Puddefoot JR, Saridogan E, et al. Angiotensin II stimulates sperm motility. Regul Pept 1996;67:131-5. [CrossRef]

37. Dzau VJ, Brody T, Ellison KE, Pratt RE, Ingelfinger JR. Tissuespecific regulation of renin expression in the mouse. Hypertension 1987;9:III36-41. [CrossRef]

38. Krege JH, John SW, Langenbach LL, Hodgin JB, Hagaman JR, Bachman ES, et al. Male-female differences in fertility and blood pressure in ACE-deficient mice. Nature 1995;375:146-8. [CrossRef]

39. Kim HS, Krege JH, Kluckman KD, Hagaman JR, Hodgin JB, Best CF, et al. Genetic control of blood pressure and the angiotensinogen locus. Proc Natl Acad Sci U S A. 1995;92:2735-9. [CrossRef] 